\title{
A pulmonalis vénaizoláció kuratív szerepe tachycardia-bradycardia szindrómában
}

\author{
Riesz Tamás János, Pap Róbert, Sághy László
}

\author{
Szegedi Tudományegyetem, Általános Orvostudományi Kar, II. sz. Belgyógyászati Klinika és Kardiológiai \\ Központ, Szeged
}

\begin{abstract}
A paroxizmális pitvarfibrillációban szenvedő beteg presyncope miatt került kórházba. Panaszai hátterében tachycardia-bradycardia szindróma (TBS) igazolódott, a pitvarfibrilláció (PF) megszűnésekor szignifikáns pauza lépett fel, amely egy alkalommal syncopéval is társult. Pacemaker- (PM) beültetés szükségessége merült fel, de a pitvarfibrilláció egyértelmű kóroki szerepe miatt pulmonalis vénaizoláció (PVI) történt, amely korai rekurrencia miatt megismétlésre került. A pitvarfibrilláció megoldásával a bradycardia és a tachycardia egyaránt megszűnt, és hosszabb távú utánkövetés során sem tért vissza.
\end{abstract}

Kulcsszavak: tachy-brady szindróma, pitvarfibrilláció, PVI, sinuscsomó-diszfunkció, syncope

\section{Curative role of pulmonary vein isolation in tachycardia-bradycardia syndrome}

The patient with paroxysmal atrial fibrillation (AF) was admitted to the hospital with symptoms of presyncope and a single episode of complete syncope. During close observation, atrial fibrillation was registered with significant pause after the cessation of AF paroxysms, that caused syncope. She was referred for pacemaker (PM) implantation, however, considering the pathophysiological role of atrial fibrillation, pulmonary vein isolation (PVI) was performed instead, that had to be repeated due to early recurrence. Following the redo PVI, tachy- and bradycardia were both eliminated, and no recurrence occured during long term follow-up.

Keywords: tachy-brady syndrome, atrial fibrillation, PVI, sinus node dysfunction, syncope

\section{Bevezetés}

A paroxizmális pitvarfibrillációban (PF) szenvedő betegek az általánosan jellemző palpitációs panaszok mellett megszédülések, akár eszméletvesztések miatt kerülhetnek sürgősségi ellátásra. Ennek hátterében gyakran tachycardia-bradycardia szindróma (TBS) áll, mely a sick sinus szindróma egy speciális fajtája, amelyben a magas frekvenciájú paroxizmusokat pauzák követik. Ezek elsősorban sinusleállás következményei, ezért gyakran pacemaker (PM) beültetés is történik. A tachycardia-bradycardia szindróma kezelésében ez a terápiás stratégia ugyan a syncopék megszünését eredményezheti, de nem változtat a rendszeresen fellépő és kellemetlen pitvarfibrillációs rohamok okozta panaszokon és következményeken.

Ismertté vált, hogy pitvari tachyaritmiák a sinuscsomóban bekövetkező elektromos remodelling következ- ményeképpen diszfunkciót okozhatnak, amely a gyors ritmuszavar tartós megszűnése vagy megszüntetése után reverzibilis lehet (1).

\section{Esetismertetés}

A 71 éves nőbeteg gyakori presyncopék, TBS tünetei miatt került felvételre PM-implantáció elbírálása céljából. Kórelőzményében hipertónia, fél éve paroxizmális PF szerepelt, spontán szünő rohamokkal. A megszédülések átlagosan heti 2 alkalommal fordultak elő eszméletvesztéshez közeli helyzetet eredményezve, és egy alkalommal teljes syncope is fellépett. Lényeges strukturális szívbetegség nem volt bizonyítható, echokardiográfiás vizsgálat jó balkamra-funkciót igazolt. Bradycardizáló szert nem szedett, bradycardiát okozó ioneltérést nem észleltek. 


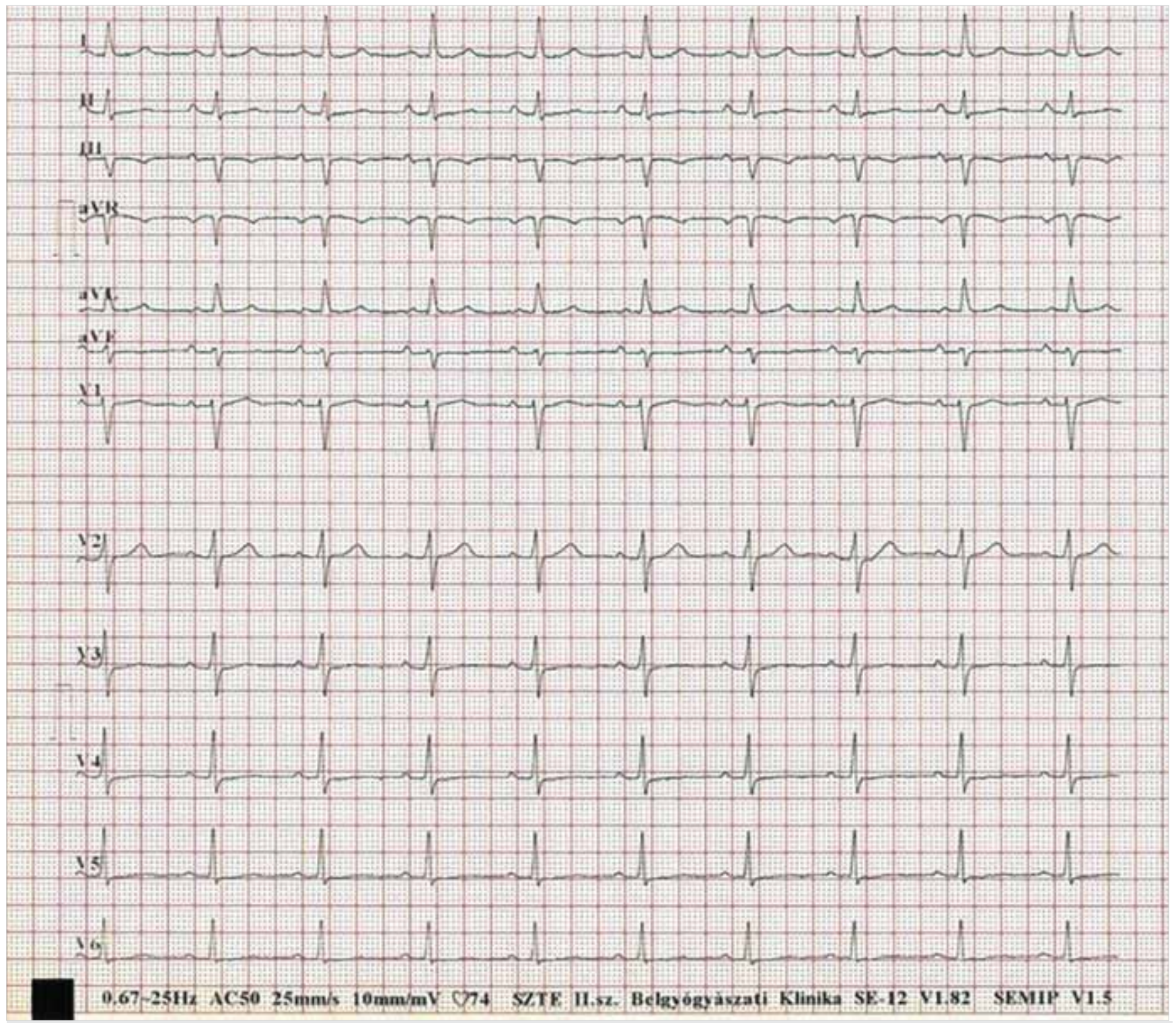

1. ÁBRA. A beteg ritmuszavarmentesen regisztrált EKG-ján látható normofrekvens sinusritmus

A beküldő által PF került a rosszullétek kapcsán dokumentálásra (2. ábra), annak megszűnésekor pedig többször sinus-, illetve junkcionális bradycardia, valamint gyakori, akár 6000 milliszekundumnál hosszabb pauzák voltak láthatóak sinusleállással (3. és 4. ábra). Mivel a pauzák igazolhatóan csak a PF megszűnésekor jelentkeztek, pacemaker-implantáció helyett a beteg részletes felvilágosítását és a vele történt egyeztetést követően pulmonális vénaizoláció (PVI) melletti döntés született. Az elektrofiziológiai vizsgálat és rádiófrekvenciás (RF) abláció során a „culprit” véna a bal közös tüdővénatörzs volt, majd az empirikus, jobb és bal tüdővénákat egyaránt magába foglaló izolációt követően a ritmuszavar megszünt. A beteg panaszai ezután ideiglenesen szüneteltek, de mobilizációját követően, akut rekurrencia részjelenségeként ismét PF-paroxizmusok jelentkeztek. Bár a már ismert sinuscsomó-diszfunkció okozta jelenségek enyhébb formában ekkor is felléptek, de az első beavatkozást követően lényegesen ritkábban jelentkeztek, amely lehetővé tette otthonába bocsátását.

Fél év múlva további késői rekurrencia miatt második PVI került elvégzésre. Ennek során a jobb felső és alsó PV rekonnekciója, illetve az innen származó repetitív PF igazolódott, amely a reizolációt követően megszűnt. Ez követően a beteg további megfigyelése során ismételt PF, presyncope, gyengeség nem jelentkezett.

Három év utánkövetés után ritmuszavar nem volt igazolható, a presyncopék és a palpitációk egyaránt megszüntek, a beteg normofrekvens sinusritmusban van antiaritmiás gyógyszerelés nélkül.

\section{Megbeszélés}

Ismert, hogy a PF-fel járó elektromos remodelling bizonyos esetekben a ritmuszavar megszűnését köve- 


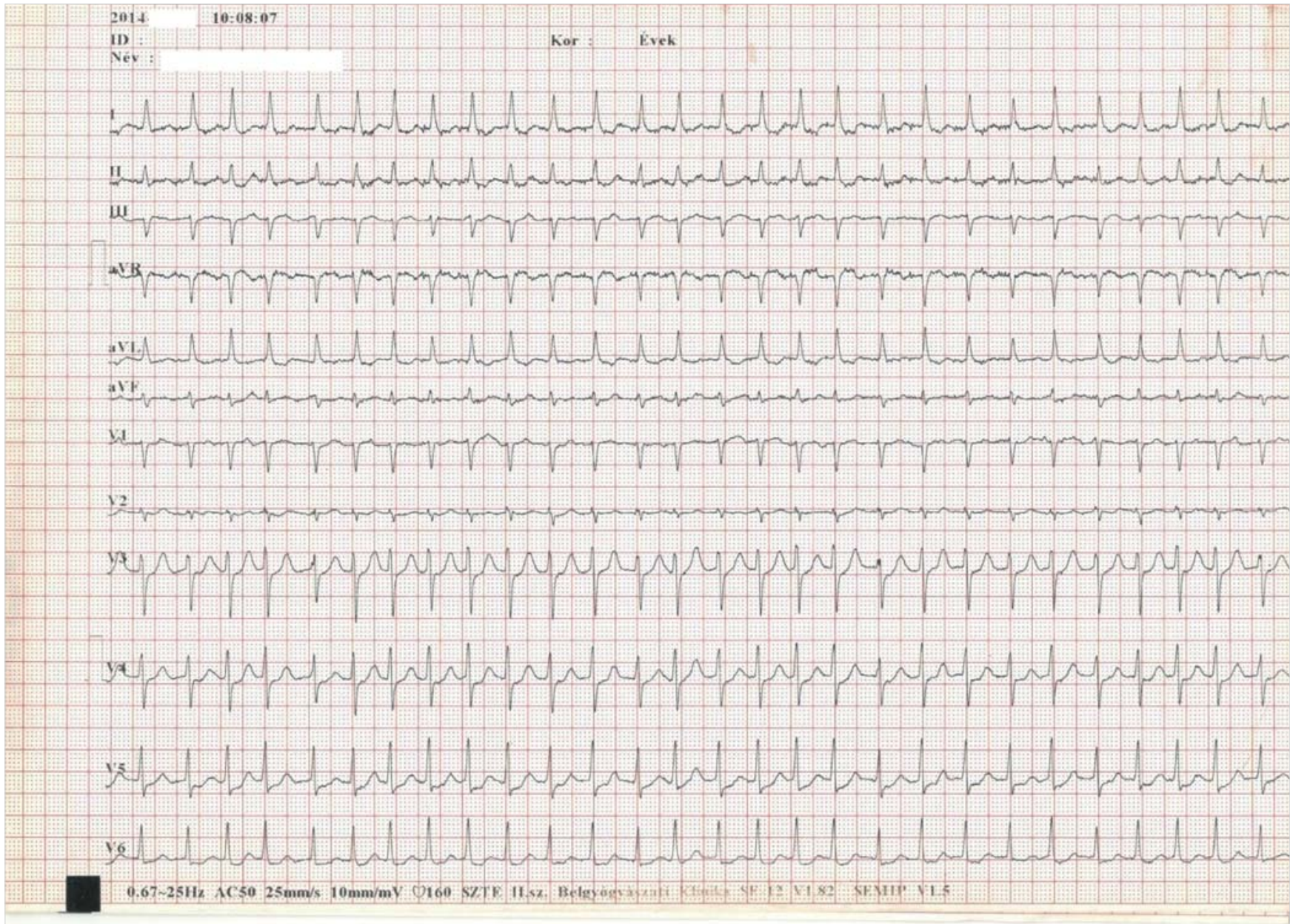

2. ÁBRA. Magas kamrai frekvenciájú pitvarfibrilláció

II

(5s

3. ÁBRA. Pitvarfibrilláció leállását követő asystolia

tően sinuscsomó-diszfunkcióhoz, következményes sinus bradycardiához vagy akár ideiglenesen junkcionális pótritmushoz vezethet (2). Ennek következtében a klasszikus intrinsic okra visszavezethető sick sinus szindrómában is megfigyelhető tünetek jelent- kezhetnek. Amíg azonban a sinuscsomó strukturális károsodásából fakadó tünetek irreverzibilis jelleggel lépnek fel, addig irodalmi adatok alapján valószínü, hogy a pitvari tachyaritmia megszüntetése a sinuscsomó-diszfunkció megszűnését és következménye- 


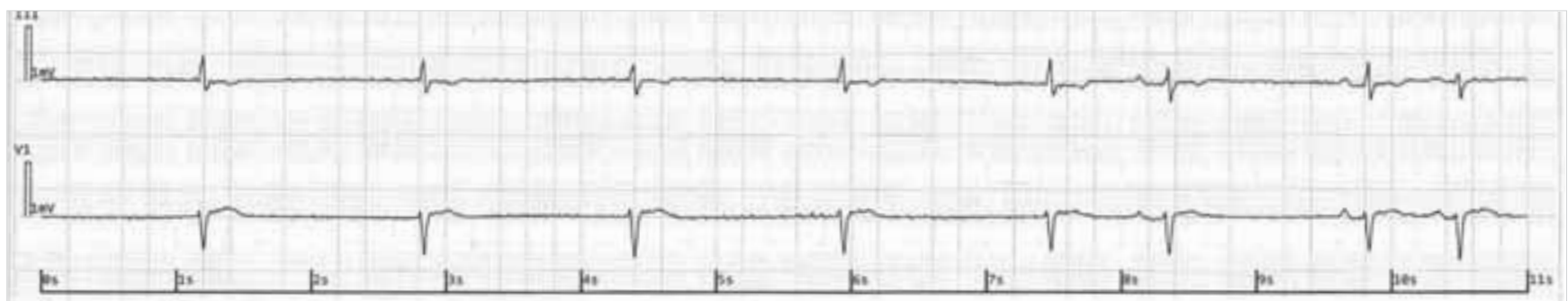

4. ÁBRA. A PF terminálódását követően regisztált junkcionális ritmus

sen a bradycardia, valamint a panaszok elmúlását is okozhatja (3). A jelenség patofiziológiai magyarázata, hogy a sikeres abláció után a sinuscsomóban ún. reverz remodelling történik, amelynek hatására nő az átlagfrekvencia és csökken a frekvenciavariabilitás (1).

Khaykin és munkacsoportjának vizsgálatában 31 sick sinus szindrómában szenvedő beteg esett át PVI-n, köztük 6 beteg már korábban PM-mel rendelkezett. Redo-PVI 4 esetben volt szükséges, ezek közül 2 esetben jelentkezett ismét rekurrencia. Sikeres PVI után minden esetben megszűntek a korábbi syncopék/presyncopék, illetve a már PM-mel rendelkező betegek esetében a pace-arány 1/13-adára csökkent (4).

A fentiekhez hasonlóan Inada és munkatársai 37 TBS-s PVI-n átesett beteg 5 éves utánkövetésének elemzése során azt tapasztalták, hogy a betegek 86\%-a tachy- és bradycardiamentes maradt az utolsó ablációt követően, 92\%-ban ismételt bradycardia nem igazolódott. A fennmaradó 3 beteg PM-beültetésen esett át, 1 beteg progrediáló sinuscsomó-diszfunkció, 2 beteg pedig visszatérő TBS miatt, ezért a szerzők a TBS-betegek esetében is a rendszeres kontrollvizsgálat és hosszú távú utánkövetés fontosságát hangsúlyozták.

\section{O̊sszefoglalás}

Az esetismertetésben szereplő betegben sinuscsomó-diszfunkció igazolódott következményes pauzával, illetve junkcionális ritmussal, amely presyncopés panaszokhoz vezetett. A regisztrált pauza mértéke alapján önmagában PM-implantáció is felmerülhetett volna, azonban - mivel bradycardia csak a PF után jelentkezett - a ritmuszavar sikeres katéteres ablációjával a tachyaritmia mellett a sinuscsomó-diszfunkció is hoszszabb távon megszüntethető volt.

\section{Irodalom}

1. M Hocini, P Sanders, I Deisenhofer, et al. Reverse remodelling of sinus node function after catheter ablation of atrial fibrillation in patients with prolonged sinus pauses. Circulation 2003, 108: 1172-1175. doi: 10.1161/01.CIR.0000090685.13169.07

2. Mark R Boyett, Gwilym M Morris, Biology of the Sinus Node and its Disease Arrhythm Electrophysiol Rev. 2015, 4(1): 28-34. doi: 10.15420/aer.2015.4.1.28

3. K Inada, T Yamane, K Tokutake, et al. The role of successful catheter ablation in patients with paroxysmal atrial fibrillation and prolonged sinus pauses: outcome during a 5-year follow-up. Europace 2014, 16: 208-213. doi: 10.1093/europace/eut159

4. Y Khaykin, NF Marrouche, DO Martin, et al. Pulmonary vein isolation for atrial fibrillation in patients with symptomatic sinus bradycardia or pauses. J Cardiovasc Electrophysiol. 2014, 15: 784-789. doi: 10.1046/j.1540-8167.2004.03279.x

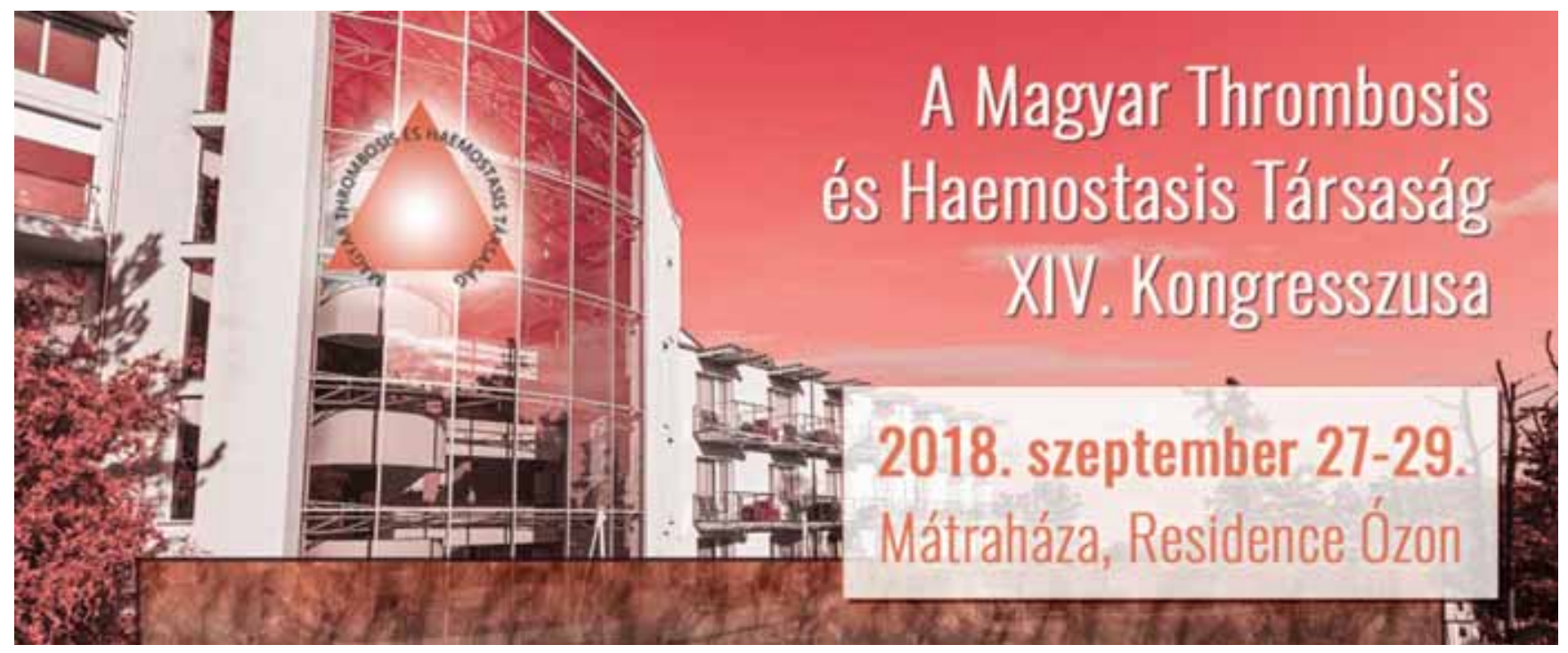

